\title{
Sleeping with the enemy: personal processes and the creation of a costume designer in times of personal wars.
}

Dormindo com o inimigo: processos pessoais e a criação de uma figurinista em tempos de guerras pessoais

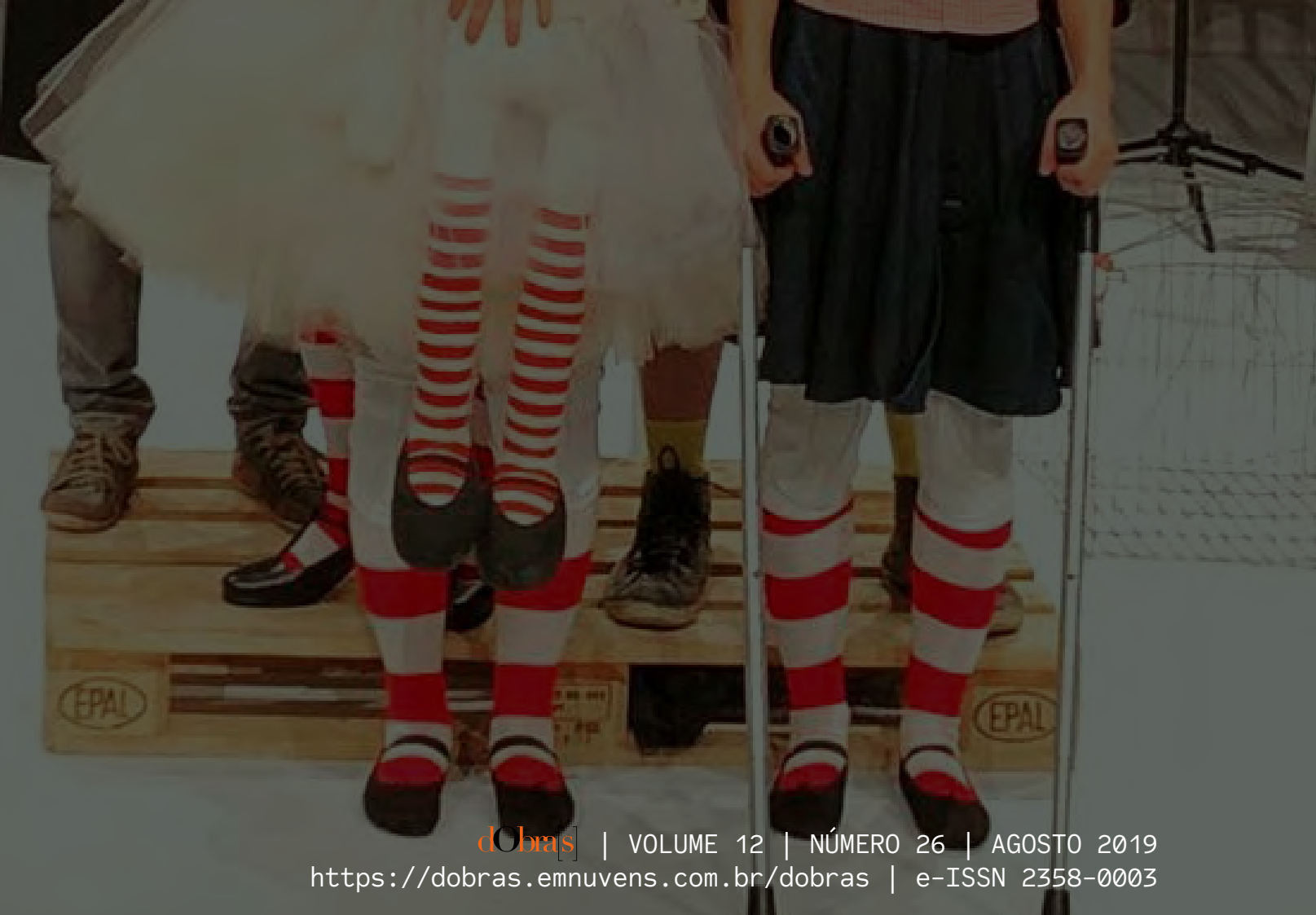


A life in design in the midst of war? It's a big, powerful thought. Can creative practice survive the horror and insanity of trauma? How might these forces impact on self-expression, the urge to create, to exist? And in my case, can there be a war in little, mortal combat played out by two people with their home providing the battlefield? Hands that loved now threaten, strong white hands that no longer caress but slap and strangle, horrible fathomless anger rules the day.

I lived out years and months with this threatening situation as my husband's mental state slid inexorably from eccentric to paranoid to psychotic. The slow progress of his deterioration and the great love and connection I felt for him, even at the end of his life - for he did kill himself in the end, and declined to kill me - made it hard to recognise how bad things had become, how dangerous everyday life was.

Do citizens dodging snipers or mines or airstrikes refuse to recognise the danger that surrounds them, in order to live some semblance of a normal life? This was certainly the case with me; I got up, went to work, socialised with friends, taught students and designed costumes, all with a sword hanging over my head.

In common with almost all victims of domestic violence, I said nothing about the troubles at home. Towards the end of a long marriage, friends could see the toll the atmosphere of hatred and violence was taking on me but they withdrew rather than speak up. I was trapped in a conspiracy of silence and isolation and in terrible danger. So much of my life was frozen, impenetrable, in incommunicado and yet my imagination ran on, unfettered and alive.

Clearly, denial helps here: I was too frightened to acknowledge the poverty of my existence or the danger in which I was. Indeed, when my husband killed himself, I was more shocked than anyone we knew. But you might imagine that the control necessary to block out such a major part of my existence would inevitably impact on my creative life.

It didn't seem to be the case; ideas flowed free and I found writing and teaching as easy and pleasant as ever, even if my temper seemed frayed and overactive. In many ways, this situation - unbearable tension and disappointment at home and joy in work - was familiar to me.

All through my childhood, my mother had been angry and disappointed in me, belittled my artistic efforts and trashed my appearance and character, labelled me dirty, ugly, destructive and a failure - and all through my childhood I adored school time and the chance to read, draw and learn. In later life when I came upon Alice Miller's book The Drama of Being a Child I was stunned to see a portrait of myself and my mother; it made so much of the nonsense into sanity.

So I took my damage, as all of us do, from childhood into the grown-up world, married an unforgiving narcissist and continued to write, read and draw. The turf war that raged over our home came to an end at my careful and persistent insistence. Fearful of what he might do to me, the house, or our pets, I gave my husband an ultimatum - to move out and

\footnotetext{
${ }^{1}$ Professora de indumentária e traje de cena na Universidade de Bristol, no Reino Unido. Atua como figurinista em várias produções teatrais na Inglaterra. E-mail: pamtait11@gmail.com.
} 
move on, then waited for him to comply. If anything, this deepened the denial needed to function. Things had become even more terrifying with my husband visibly fighting, on an everyday basis, an urge to kill me and have done with the situation.

It came very close once; he gripped my neck and shouted at me to answer a question "yes" or he would continue to grip my neck and I would lose consciousness in minutes. I can't remember the question, but I found out later that the hold he had me in would cause unconsciousness in around 2 or 3 minutes, and then death in around 5. Close call I brought... and went to work.

In this period of what turned out to be the end game, I was involved in putting on a devised performance by the final years in the university drama department where I worked. It was a wonderful time there; practice as a researcher was a fundamental of the teaching, and the students were bright keen and inspired.

Often collaborations between me and my students would prove seamless - after a particularly wonderful production of the Oresteia, a fellow tutor remarked the fury costumes (wax printed, padded, and dyed with claws and tufts of hair and clotted bloody dreadlocks, truly horrible) that I had designed, of course. I had indeed bought a set of odd red dresses which provided the basis for the costumes, but I genuinely couldn't say which ideas had been whose in the production process; we seemed to be operating on the same intensely imaginative and pragmatic plane.

Experiences such as these certainly held off the horror of my situation; truly collaborative creative work is a bliss that few achieve. The final year production I was working on in the weeks that led up to my husband's leaving and death was devised and very complex.

The opening of the show began behind plastic, with the students in flesh coloured sequins and soft silver costumes, shoaling together. Several duets and trios followed in moving surreal sets in crazy colours and clothes; there was a feeling for fragility, movement, oddity. The climax of the piece was a wild homage to Nick Cave's sound suits and to drag. Boas and neon colours abounded, electric coloured gimp masks were worn, three of the boys stripped to tiny shiny thongs. As the final dance exploded to the sounds of coughing, the cast disappeared, one by one, and re-emerged in white underwear and miniskirts and lined up in front of a projection of themselves in white underwear and miniskirts.

At a late stage in the technical get-in, my phone rang; my husband had been staying in a hotel in town and had gone missing late at night. Amongst writings in his room the hotel staff had found death threats for me, and they were sending the police to the department. A policewoman arrived, chatted and suggested that we go to my house to look for anything suspicious or deadly - a sword or knife perhaps - that might be missing, something my husband might use to kill me. Fully aware of the danger in his hands, I agreed to accompany the policewoman.

By the time I had returned with my coat the officer had had news: my husband had been found, dead.

I did go home then, to tell everyone that it was over and to begin the very long process of recognition of the danger in which I had been, to be followed by the very long process of grief for the loss of my twin spirit.

Things were not easy: anger and fear came out roaring into my life and nearly wrecked my career. It was very hard to exist. 
After a year of sick leave, I came back to work and a freelance project. Working with a dance company which was beginning to transition from mainly cabaret and festival shortform performances, I helped put on a Max Ernst photolithographic novel, The young Girl longs for the veil. It was difficult to adapt, I didn't know the dancers very well, and I respected them a great deal; the process was delicate and tricky.

The result was spectacular, funny surreal, horrifying in turn, the dancers were superb and my costumes many, various and excellent.

I had a strange feeling of lightness at the opening of the show. Obviously I was delighted that the piece was finally on - there had been an awful lot of costumes and even more negotiation. It had been difficult enough to manage my still stunned and exhausted state; I wanted to work with the group forever, they were so insanely talented and kind and imaginative, so I was pleased that they were pleased. But the lightness came from another source: for the first time since my husband's death and the utter collapse of my world that followed, I had made a good and beautiful thing.

It was at this point that I realised that I had been in denial about a very serious question - had all that had happened destroyed my creative genius? The wounds sustained in the years of madness and marriage had not proved fatal, although I was what you might call walking wounded for a very long time. I was now free to live out my life in new and better ways.

I moved far away and began again, in hope and peace.

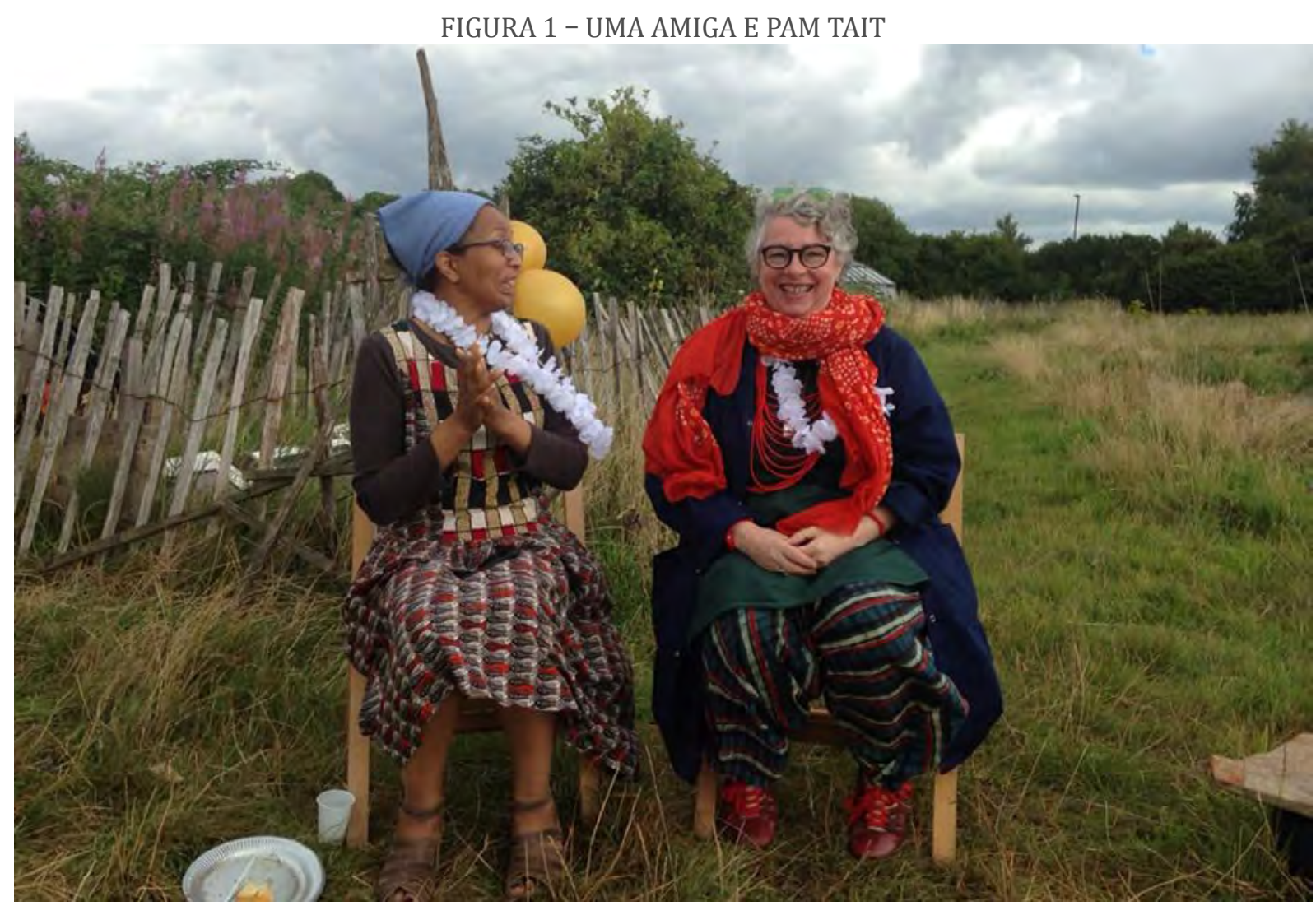

FONTE: fotografia publicada no Facebook de Pam Tait. 18 ago. 2015. 